\title{
Finger surgery for deafness: rethinking quackery in medical history
}

— Cite as: CMAJ 2019 February 19;191:E192-4. doi: 10.1503/cmaj.180989

n 1923, American news dispatches announced that King Alfonso of Spain had summoned a famous New York osteopath to treat his 15-year-old son, Infante Don Jaime (1908-1975). Deaf and mute following a severe case of mastoiditis, Don Jaime was judged "incurable" after Spanish specialists unsuccessfully operated on him in 1912. ${ }^{1}$ According to court insiders, an osteopath took only 20 minutes to perform a bloodless and painless operation that miraculously cured the prince. Who was this osteopath who had succeeded where all others had failed? Reporters deduced that one man fit the bill: Brooklyn-based Dr. Curtis $\mathrm{H}$. Muncie (1887-1963), who happened to be sailing on the Majestic, which was bound for Europe, to promote his "constructive bi-digital intra-aural" technique, otherwise known as the "Muncie Reconstruction Method" or simply "finger surgery." The technique required Muncie to insert his fingers through a patient's larynx to manipulate the eustachian tube and manually correct aural defects causing deafness. Allegedly, it had a $90 \%$ success rate in incurable cases. ${ }^{2}$

The reports turned out to be false. Upon returning to the United States, Muncie was accused of using Don Jaime to promote his technique. In defence, Muncie sent out a press release that the criticism was "an unfair and malicious attack" on him and his method, likely launched by enemies of osteopathy who were threatened by his financial success. ${ }^{3}$ He clarified that he had sailed for Europe but never said - nor ordered anyone to say on his behalf - that he treated the Spanish prince. Despite criticism, the Don Jaime fiasco projected Muncie into the spotlight, as newspapers and magazines profiled his

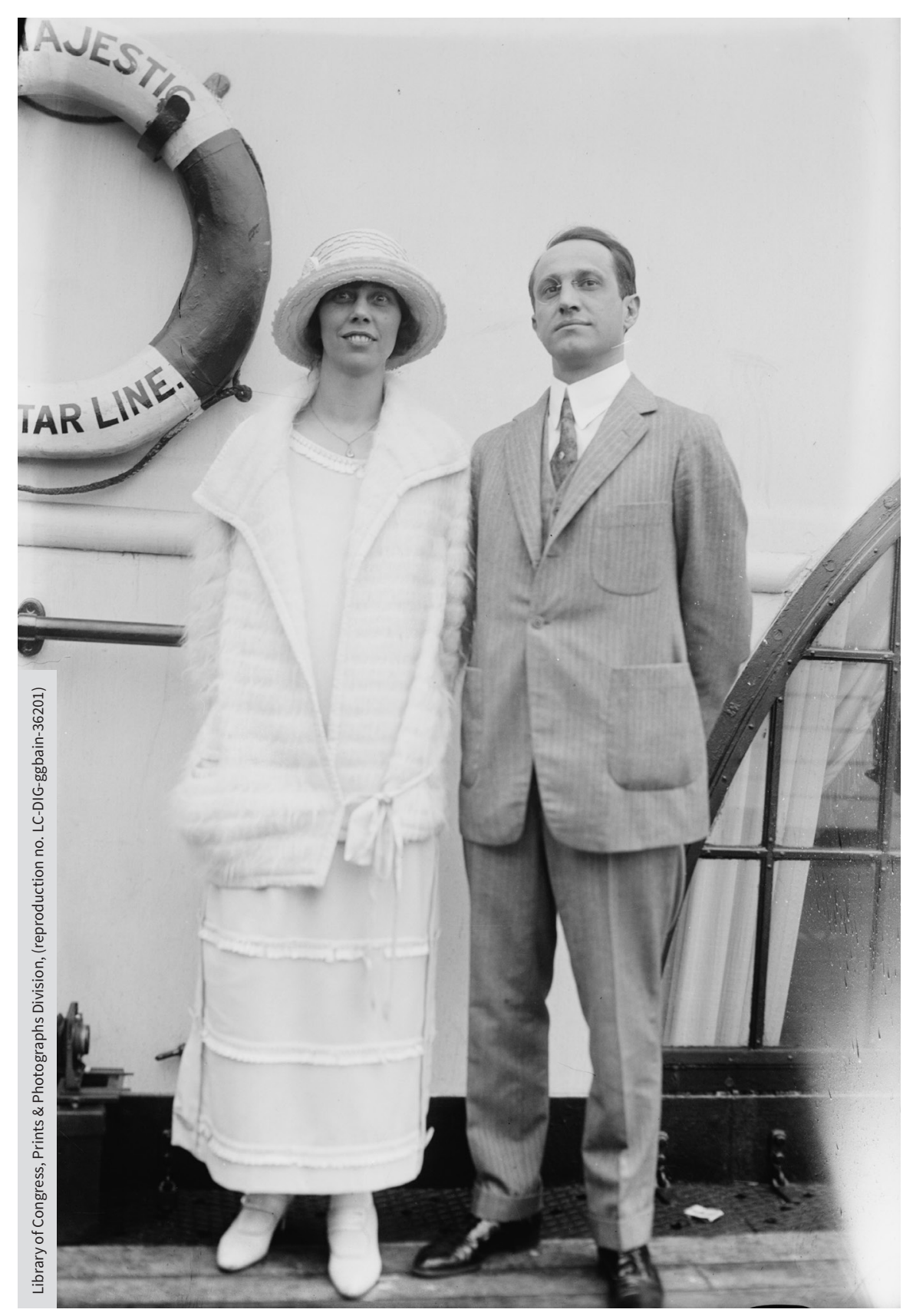

Mrs. Ada B. Hicks and Dr. C.H. Muncie, circa 1900, Bain News Service. From the George Grantham Bain Collection, United States Library of Congress, Washington, D.C. 
finger surgery and proclaimed it to be a miracle cure for deafness. On any given day, upward of 200 patients lined the corridors on the 29th floor of the fashionably exclusive Hotel Delmonico in Manhattan waiting to be treated. ${ }^{4}$ Over the course of his 5-year career, Muncie allegedly treated 1585000 cases using finger surgery and even had his hands insured for $\$ 400000 .^{2}$ His practice was so successful that rumours swirled that he had generated more than half a million dollars during the Great Depression. ${ }^{5}$

No favourable magazine profile, however, could quell attacks against Muncie from the public and the medical profession that he was a palpable faker who deluded victims with his unscrupulous business tactics. Dr. George E. Shambaugh (1869-1947), one of the leading otologists of the time, impugned Muncie as a notorious fraudster with his "silly finger surgery." ${ }^{\prime}$ The American Medical Association (AMA) insisted that Muncie's technique lacked any sound scientific support and was the "worst deafness cure fraud" of the 1920s and 1930s; the association's journal even editorialized that "Muncie may well rank among the leading charlatans of our time." Muncie's advertising, promotions and boastful pretensions are all traditional indicators of medical quackery as outlined by the AMA, but these perspectives do not explain why thousands of deaf Americans flocked to his office seeking treatment. Contextualizing the popularity of finger surgery within the backdrop of professionalization and the shifting cultural perspectives of deafness allows us to frame a more nuanced picture of medical quackery.

Early 20th-century medicine was fragmented. In its attempts to secure monopoly and define professional standards, the medical establishment attempted to outlaw sectarian competition that it perceived would threaten the therapeutic consensus of the profession - "cults" as they were called - including osteopathy.

A health-reform movement founded by Dr. Andrew Taylor Still (1828-1919), osteopathy is based on the principle that disease is rooted in a disordered musculoskeletal system, interfering with the nerves and blood supply. Physically manipulating the body's bones, tissues and muscles with limited use of instruments releases the interference without the adverse effects of pharmaceuticals. Despite hostile legislative attempts by allopaths to limit the autonomy of osteopaths, by the 1930 s osteopathy had solidified into a distinct field with its own institutions, journals and licensing boards. ${ }^{8}$

Indeed, within the osteopathic community, Muncie was perceived as qualified and trained, having published about 60 articles in various osteopathic journals. Muncie initially studied chemical engineering at the Brooklyn Collegiate and Polytechnic Institute but decided to shift his career to medicine, probably at the behest of his parents, Edward and Elizabeth Muncie, who established the Muncie Sanatorium in Brooklyn in 1896. Although the elder Muncies provided homeopathic care to patients with chronic diseases, their son decided to matriculate at the Philadelphia College and Infirmary of Osteopathy before transferring to Still's American School of Osteopathy in Kirksville, Missouri. After graduating in 1910, he returned to Brooklyn to work at the Muncie Sanitarium.

As Muncie explains in his advertising booklet, Prevention and Cure of Deafness, after a routine examination of an 11-yearold boy deafened by scarlet fever, he became interested in aural disorders. Following standard removal of the boy's adenoids, Muncie examined his nasopharynx with a finger and "found lateral adenoids remaining, which had grown about the orifices of the eustachian tubes."2 He broke the adenoids down and, much to his surprise, his fingers slipped into the eustachian tube, challenging conventional anatomic findings that the tube was no larger than a goose quill. Although the boy's hearing was "miraculously" restored, the effects lasted for only 2 weeks. Wanting to develop a more permanent solution, Muncie examined over 500 eustachian tubes of patients at the Sanatorium during 1910-1916 and concluded that the tube "is larger in life than in death - large enough to be treated digitally." He claimed to have restored the boy's hearing by digitally correcting the defective eustachian tube. Muncie's claim of "inventing" finger surgery, however, was questioned; supposedly, laryngologist Dr. Frank E. Miller was the originator of the technique as early as 1893 but failed to convince his conservative colleagues of its benefits. ${ }^{9}$

In 1921, Muncie correlated his findings to announce 2 major claims: the eustachian tube differed in size, contour and tone in people who are deaf and that deformity in the eustachian tube was a universal cause of deafness. Furthermore, he identified 11 types of deafness, 10 of which were curable by his surgery; only cases of deafness due to nerve degeneration from meningitis were not suitable candidates - although he still accepted patients with this condition.

Although Muncie argued that even the slightest tubal deformity could be digitally manipulated to cure deafness, he insisted his method could not be taught. Instead, he offered demonstrations in more than 50 cities in the US and Europe; these demonstrations elevated Muncie to celebrity status. It was, however, an expensive procedure: an examination cost $\$ 25$, operations began at $\$ 200$, and postoperative treatment was $\$ 10$. Comparatively, a stay at the Hotel Waldorf in New York City cost $\$ 5$ to $\$ 10$ a night.

The popularity of finger surgery as a cure for deafness certainly reflected broader cultural expectations of normalcy and eugenics that required American citizens who were deaf to be godly, educated and civic minded. ${ }^{10,11}$ To fit with these expectations, they had to become "hearing" or at least "pass" as such if their hearing could not be restored, by embracing adaptative strategies such as lip-reading, wearing hearing aids or, if desperate enough, trying unconventional therapies. Furthermore, the addition of audiometric screening and collaborative programs between telecommunications companies, social welfare organizations and leading otologists reinforced the notion that hearing loss was "preventive" and that deafness was an individual responsibility; thus, assimilating was required for all citizens who were deaf.

Muncie actively engaged in battles over jurisdictional authority of patients who were deaf by harshly condemning allopaths and their theories that otosclerosis and Ménière disease were causes of hearing loss; nevertheless, allopathic treatments for catarrhal deafness followed 
similar techniques to Muncie's, and osteopaths continued to devise and use modified versions of the Muncie method. ${ }^{5,12}$

However, not all patients benefited from Muncie's method. Indeed, some of his patients wrote to the AMA to express their dissatisfaction and regret over lost funds - \$3000 or more - and shared their disappointment at discovering that yet another treatment could not restore their hearing (Historical Health Fraud and Alternative Medicine Collection at the AMA archives, folder "Muncie, Dr. Curtis H., Correspondence, 1921-1927" [Box 519, Folder 09]). Others wrote to denounce the AMA's substantial attacks against Muncie, arguing that his promotional materials and success stories were necessary for providing hope to those who were deaf and to restore their confidence in the medical profession.

At the end, it was not professional criticism that destroyed Muncie's career, but his 1939 arrest for income tax evasion.
After his release from prison, he passed his business to his son Douglas, who eventually established the Muncie Institute for Hearing in Miami and Las Vegas, where he practised until 1976, supposedly treating more than 4000 patients using his father's "unteachable" technique.

\section{Jaipreet Virdi MA PhD}

Department of History, University of

Delaware, Newark, Del.

\section{References}

1. Powell C. Juan Carlos of Spain: self-made monarch. London (UK): MacMillian Press; 1996.

2. Muncie $\mathrm{CH}$. Prevention and cure of deafness through Muncie reconstruction method. 4th ed. New York; 1936:52.

3. Curtis H. Muncie to Volta Review, 25 Nov. 1923. Department of Investigation Records, Historical Health Fraud and Alternative Medicine Collection, American Medical Association.

4. Crowds wait for 'finger surgeon' to heal deafness. Buffalo News Courier 1923 Apr. 6. Department of Investigation Records, Historical Health Fraud and Alternative Medicine Collection, American Medical Association.

5. Swamy RS, Jackler RK. The fickle finger of quackery in otology: the saga of Curtis H. Muncie, osteopath. Otol Neurotol 2010;31:846-55.

6. Letter from G.E. Shambaugh to M. Fishbein, Feb. 16, 1923. Department of Investigation Records, Historical Health Fraud and Alternative Medicine Collection, American Medical Association.

7. Current Comment. U.S. finds 'finger surgeon' fraud in income tax. JAMA 1942;119:799.

8. Gevitz N. The DOs: Osteopathic medicine in America. Baltimore: John Hopkins University Press; 2004.

9. Finger surgery as a cure for deafness. Am Ann Deaf 1923;68:347.

10. Edwards RAR. Words made flesh: nineteenthcentury deaf education and the growth of deaf schools. New York: New York University Press; 2012.

11. Burch S. Signs of resistance: American deaf cultural history, 1900 to World War II. New York: New York University Press; 2002.

12. Channell MK. Modified Muncie technique: osteopathic manipulation for eustachian tube dysfunction and illustrative report of case. J Am Osteopath Assoc 2008;108:260-3.

This article has been peer reviewed. 